\title{
CD20 role in pathophysiology of Hodgkin's disease
}

\author{
Marcelo Antônio Oliveira Santos ${ }^{1 *}$, Marinus de Moraes Lima ${ }^{2}$ \\ ${ }^{1}$ Medical Student, Centro Universitário Maurício de Nassau and Scientific Director of the Epidemiology and Cardiology Research Group, Universidade Federal de Pernambuco, Recife, PE, Brazil \\ ${ }^{2} \mathrm{MD}$ Hematologist, Hospital do Câncer de Pernambuco, and Associated Professor of Medicine (Hematology), Centro Universitário Maurício de Nassau, Recife, CE. MSc in Pharmacology from \\ Universidade Federal do Ceará, Fortaleza, CE, Brazil
}

Study conducted at Centro Universitário Maurício de Nassau, Recife, PE, Brazil

Article received: $12 / 15 / 2016$ Accepted for publication: 2/5/2017

*Correspondence: Centro Universitário Maurício de Nassau Address: Rua Jonathas de Vasconcelos, 316, Boa Viagem Recife, PE - Brazil Postal code: 51021-140 marcelosantos.med@gmail.com

http://dx.doi.org/10.1590/1806-9282.63.09.810

\section{SUMMARY}

Hodgkin's lymphoma (HL) is a tumor comprising non-malignant and malignant B-cells. Classical HL expresses CD15+ and CD30+ antigens, and 20 to $40 \%$ of patients are $\mathrm{CD} 20+$. This antigen is a ligand free protein present in $\mathrm{B}$ lymphocyte cells and its function is not well known. Some studies suggest that expression of CD20 may play a major role in Hodgkin's disease pathophysiology and may affect the patients' treatment prognosis, as well as relapse and refractory response. In the past few years, development of monoclonal anti-CD20 antibodies changed drastically the treatment for non-Hodgkin lymphomas in which CD20 is expressed. HL treatment is essentially composed of radiotherapy and chemotherapy; however, monoclonal anti-CD20 antibodies applicability is not well delimitated due to lack of information about clinical outcomes with anti-CD20 monotherapy or combined drug therapy using a classic regimen, as well as about CD20 pathophysiology mechanisms in B-cells tumors. The objective of our review is to discuss CD20 function in Hodgkin's lymphoma development, its influence on disease evolution and outcomes, as well as its effects on therapeutics and patients' prognostic.

Keywords: Hodgkin's disease, CD20 antigen, pathophysiology, rituximab, review.

\section{Overview}

Hodgkin's lymphoma (HL) is a tumor derived from B-cells composed by Hodgkin and Reed-Sternberg (RS) cells, which represent, respectively, mononucleated and multinucleated subtypes. In addition to these malignant cells, $\mathrm{HL}$ infiltrates comprise $\mathrm{T}$ cells, neutrophils, eosinophils, macrophages, fibroblast, plasma cells and mast cells. ${ }^{1,2}$

The malignant cells are referred to as giant cells, also denominated Hodgkin Reed-Sternberg (HRS) cells, and their origin remains controversial. ${ }^{1}$ Some theories point to either a fusion of $B$ and non- $B$ cells or mutation in germinal-center cells and loss of $\mathrm{B}$ cell receptor expression. ${ }^{1,3,4}$ HRS cells seem to be dependent on both extracellular signals and endogenous signals derived from its own genome mutation. Macrophages may play a role in tumor support. ${ }^{2}$

In all classical HL, tumor cells correlation with EpsteinBarr virus (EBV) infection occurs in about 20 to $40 \%$ of cases, but its role in pathophysiology is poorly understood..$^{4-6}$ Immunohistochemistry and gene expression profiling suggest that EBV influences the B-cell microenvironment. ${ }^{2}$
The classical presentation of HL is painless lymphadenopathy, usually cervical and/or supraclavicular. B symptoms as fever, unintentional loss of more than $10 \%$ of bodyweight over 6 months and fatigue are present in $25 \%$ of patients and have prognostic value. ${ }^{5}$

Histological subtypes of classical HL include nodular sclerosis, mixed cellularity, lymphocyte depletion and lymphocyte-rich lymphoma. Typical immunophenotype for HRS in classical HL expresses CD15, CD30 and CD20 (in about $20 \%$ of patients). ${ }^{3,4}$ There is still another subtype of non-classical HL know as lymphocyte-predominant HL (LPHL), which is characterized by presence of histiocytic cells, expression of CD20, and lack of expression of CD15 and CD30, unlike the classical presentation of HL. ${ }^{6}$

First line of treatment for classical HL includes chemotherapy and radiotherapy. The most common drug therapy regimen is adriamycin/doxorubicin, bleomycin, vinblastine and dacarbazine (ABVD). ${ }^{7}$ Most patients with classical HL have full remission after initial treatment; however, about $34 \%$ of patients with advanced disease and $15 \%$ of those with early disease experience a relapse after treatment. ${ }^{8}$ 


\section{CD20 EXPRESSION AND FUNCTION}

The CD20 antigen is a transmembrane highly hydrophobic glycosylated phosphoprotein of $\sim 35 \mathrm{kd}$ encoded in humans by the MS4A1 gene. ${ }^{9}$ Its structure is showed in Figure 1. CD20 is found in healthy mature B cells as early as in the pro-B phase, as well as in chronic lymphocytic leukemia, LPHL and in some cases of classical HL. ${ }^{4,10}$ It has a specific role in the regulation of differentiation and growth of $\mathrm{B}$ cells through cell activation from a resting state (G0) on to $\mathrm{G} 1$, as well as regulation of the cell cycle from the $S$ phase to mitosis, step-by-step. ${ }^{9}$ It is part of a cell-surface complex that regulates calcium transport and is able to initiate an intracellular signaling pathway through calcium influx. ${ }^{10-12}$ Nevertheless, disruption of calcium channel gene encoding does not demonstrate critical effects either on B-cell development or immune response implementation. ${ }^{12}$

The presence of CD20 expression in lymphocytepredominant $\mathrm{HL}$ and some presentations of classical HL support the hypothesis that HRS cells derive from germinal-center B cells at the centroblast stage. Genetic studies with mRNA and DNA demonstrate rearrangement of immunoglobulin genes and presence of mutations in variable regions of immunoglobulin heavy chain. Also, HRS cells present hypermutation in variable regions of the immunoglobulin heavy chain gene. ${ }^{7}$ Other mechanisms involved are deregulated expression of $\mathrm{B}$ cell molecules, down-regulation of $\mathrm{B}$ cell transcription factors and epigenetic silencing of $\mathrm{B}$ cell genes. $\mathrm{EBV}$ has potential to express LMP1 and LMP2A, which mimic key signals of growth and survival of $\mathrm{B}$ cells. ${ }^{13}$ These evidences could connect both hypothesis of origin of HRB cells and EBV role in HL pathophysiology.

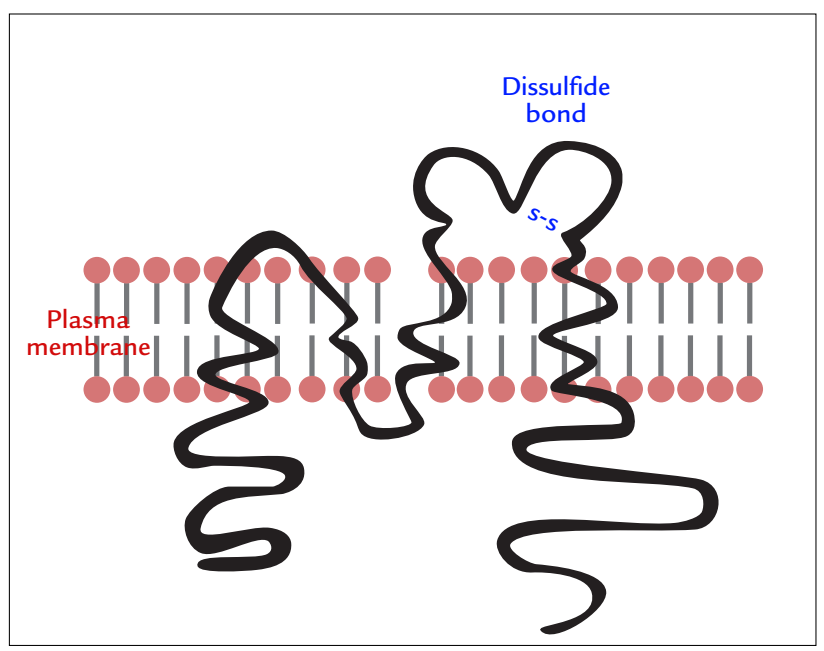

FIGURE 1 CD20 antigen structure. The disulfide bond is essential as binding site for rituximab, which is an anti-CD20 monoclonal antibody.

\section{ANTI-CD20 THERAPY}

Anti-CD20 chemotherapy is vastly used in the treatment of non-Hodgkin tumors with a high expression of CD20 antigen. The most common drugs used as anti-CD20 agents are rituximab and obinutuzumab. These are monoclonal antibodies $(\mathrm{mAb})$ that bind to the antigen ligand portion of the plasma membrane causing death of tumor cells by activation of the $\mathrm{C} 1 \mathrm{q}$ cascade, leading to complement molecules deposition on cellular surface and apoptosis by complement-dependent cytotoxicity. ${ }^{12}$

Since in classical HL it is possible to find some cells expressing CD20 antigen, studies have associated gold standard chemotherapy, ABVD and anti-CD20 mAb to evaluate if this could improve treatment efficacy. In these studies, the point was not targeting the malignant HRS cells, but the clonotypic stem cell or the B cell harbored in the microenvironment, which is called "HRS cells off-targeting". ${ }^{13,14}$ As a result, it could help to slow down solid infiltrated tumor growth, but it would not induce regression. In the other hand, there is some evidence suggesting that B lymphocytes may inhibit Th1-mediated anti-tumor responses. ${ }^{13}$ Furthermore, evidences suggest that depleting normal B cells enhances antitumor response due to decreased interleukin-10 (IL-10) production by these cells. ${ }^{14}$ All the pathways in which anti$\mathrm{CD} 20 \mathrm{mAb}$ may perform direct or indirect control over the tumor population are represented in Figure 2.

Since LPHL expresses CD20, mAb could be used as a therapy option even as monotherapy. A group at Stanford University performed a clinical trial with rituximab that resulted in an overall response rate of $100 \%$ with limited toxicity effects. Association between chemotherapy and anti-CD20 as combined therapy is highly recommended for LPHL treatment ${ }^{6}$ and for advanced classical HL or relapsed or refractory classical HL. ${ }^{14}$

\section{CD20 RELATION to PROGNOSTIC AND CLINICAL OUTCOME}

The role of CD20 as a prognostic factor remains controversial. CD20 has no known function that could imply in resistance to chemotherapy; however, it interferes in failure-free survival at 5 years, according to its expression. ${ }^{11}$

Greaves et al. demonstrated that no prognostic significance was found for CD20 expression, but nonfollicular CD20 expression influenced survival. Using 1,700 cells $/ \mathrm{mm}^{3}$ as a cut-off point, patients with high nonfollicular CD20 expression had overall survival improved $(\mathrm{p}=0.003)$ at 5 years $(87 \%$ versus $70 \%)$, at 10 years $(84 \%$ versus $52 \%$ ) and at 20 years ( $76 \%$ versus $43 \%)^{2}$

Tzankov et al., in a study with 119 patients with classical HL followed for 12 years demonstrated that immunopheno- 


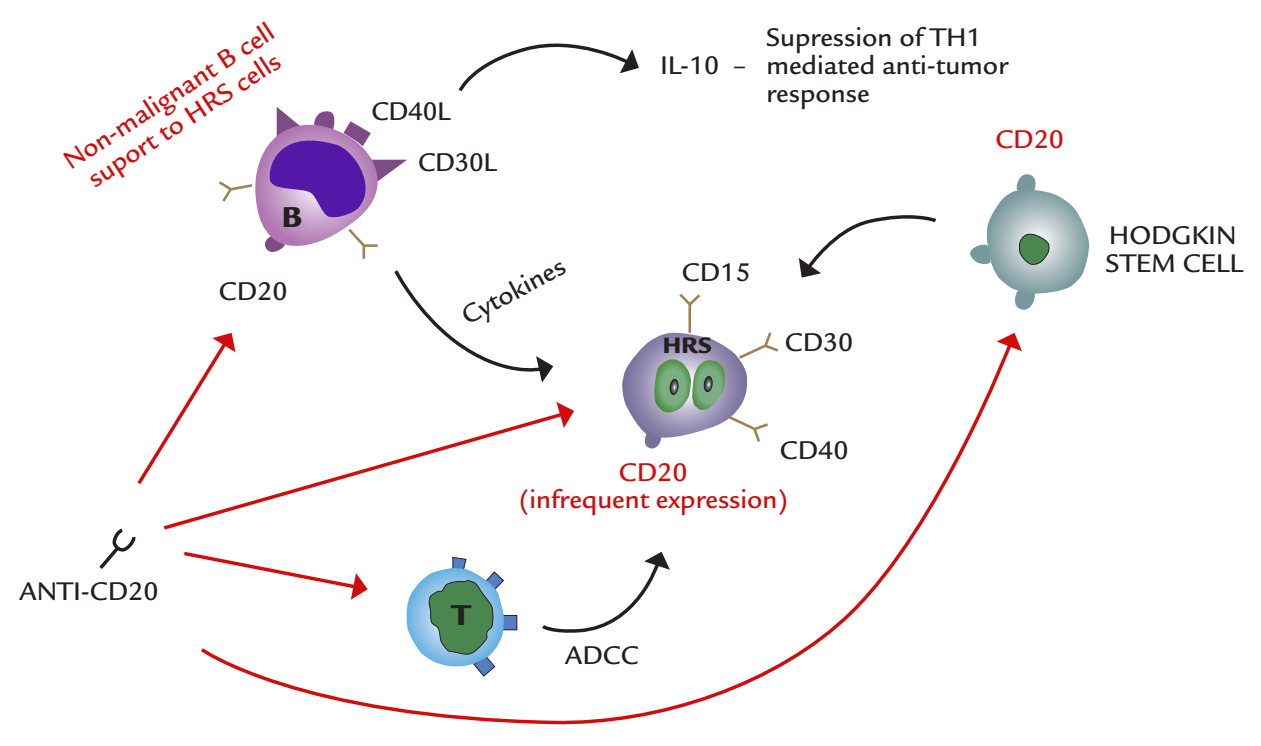

FIGURE 2 Main pathways where monoclonal anti-CD20 antibodies exert their function on Hodgkin's disease: a) inhibit Hodgkin stem cell proliferation directly, depleting new HRS cell formation; b) inhibit HBRS differentiation by binding CD20 ligand; c) activation of complement cascade through ADCC response mediated by T cells; d) depletion of support non-malignant B cells, which signals to RBS cells via cytokines and inhibit Th1 tumoral response by production of IL-10.

type CD30+/CD15 $/ \mathrm{CD} 20+$ is associated with a favorable clinical outcome and CD20 was an independent positive prognostic factor $(p=0.035)$. Failure-free survival was higher in CD20+ patients (286 months versus 202 months; $\mathrm{p}=0.022) .{ }^{15}$

Horvat et al. established a cut-off level of 25,000 molecules of equivalent soluble fluorochrome (MESF) of CD20 expression to determinate a predictive significance of better outcome with rituximab treatment. They found that patients with CD20 expression above the cut-off level had a significantly longer overall survival than those with lower levels $(\mathrm{p}=0.0383) .{ }^{16}$

\section{Conclusion}

CD20 antigen is a membrane protein without any known physiological ligand. The specific role it plays is not clear, but it has an essential function as regulator of B lymphocyte and germ-cell cell cycle, as well as on cellular growth and differentiation.

In Hodgkin's lymphoma, CD20 seems to be a marker for HRS cell origin and has a key importance in: suppression of Th1 antitumoral immune responses through IL-10 production; stimulation of non-malignant B lymphocytes through cytokine liberation, which supports HRS cell survival; proliferation of HRS cells by direct stimuli on Hodgkin stem cells.

Anti-CD20 therapy is a great modality of treatment, because of its potential to inhibit different stages in the physiopathogenesis of Hodgkin's disease. However, combined AVBD and rituximab (or another anti-CD20 mAb) seems to have a better result in advanced or relapsed/ refractory classical HL. In early stages, gold standard therapies (chemo and radiotherapy), not combined with $\mathrm{mAb}$, yield good results, except for LPHL, in which massive CD20 expression has a powerful response to $\mathrm{mAb}$ drugs even as monotherapy.

As a prognostic factor, CD20 expression is still controversial, but most studies have pointed out evidence that it could positively affect disease outcomes, and association between classic chemotherapy regimen and $\mathrm{mAb}$ drugs, especially rituximab, may improve overall survival and failure-free survival.

\section{ACKNOWLedgments}

I would like to thank Lucas Soares Bezerra, MD, for the creation and assignment of the illustrations presented in this paper.

\section{Conflict of interest}

The authors declare no conflict of interest.

\section{Resumo}

O papel do CD20 na fisiopatologia da doença de Hodgkin 
O linfoma de Hodgkin (LH) é um tumor composto por células B não malignas e malignas. O LH clássico expressa antígenos CD15+ e CD30+, mas apenas cerca de 20 a $40 \%$ dos pacientes expressa também antígeno CD20. Este antígeno é uma proteína sem ligante presente nas células de linfócitos B cuja função não é bem conhecida. Alguns estudos sugerem que a expressão de CD20 pode ter um papel importante na fisiopatologia da doença de Hodgkin e pode afetar o prognóstico dos pacientes ao tratamento, bem como recaída e refratariedade. Nos últimos anos, o desenvolvimento de anticorpos monoclonais anti-CD20 mudou drasticamente o tratamento para linfomas não Hodgkin em que o CD20 é expresso. O tratamento do LH é composto essencialmente de radio e quimioterapia; no entanto, o espaço dos anticorpos monoclonais anti-CD20 não está bem delimitado em decorrência de: falta de informação sobre o desfecho clínico, seja na monoterapia com anti-CD20, seja na terapêutica combinada com o regime clássico; falta de informação sobre os mecanismos de fisiopatologia CD20 em tumores de células B. O objetivo desta revisão é discutir sobre a função do CD20 no desenvolvimento do linfoma de Hodgkin, sua influência na evolução da doença e os resultados, bem como os efeitos sobre terapêutica e prognóstico dos pacientes.

Palavras-chave: doença de Hodgkin, antígeno CD20, fisiopatologia, rituximab, revisão.

\section{References}

1. Rengstl B, Newrzela S, Heinrich T, Weiser C, Thalheimer FB, Schmid F, et al. Incomplete cytokinesis and re-fusion of small mononucleated Hodgkin cells lead to giant multinucleated Reed-Sternberg cells. Proc Natl Acad Sci USA. 2013; 110(51):20729-34.

2. Greaves P, Clear A, Coutinho R, Wilson A, Matthews J, Owen A, et al. Expression of FOXP3, CD68, and CD20 at diagnosis in the microenvironment of classical Hodgkin lymphoma is predictive of outcome. J Clin Oncol. 2013;31(2):256-62.

3. Küppers R, Schwering I, Brauninger A, Rajewsky K, Hansmann ML. Biology of Hodgkin's lymphoma. Ann Oncol. 2002; 13(Suppl 1):11-8.

4. Küppers R, Engert A, Hansmann ML. Hodgkin lymphoma. J Clin Invest. 2012; 122(10):3439-47.

5. Townsend W, Linch D. Hodgkin's lymphoma in adults. Lancet. 2012; 380(9844):836-47.

6. Ekstrand BC, Lucas JB, Horwitz SM, Fan Z, Breslin S, Hoppe RT, et al. Rituximab in lymphocyte-predominant Hodgkin disease: results of a phase 2 trial. Blood. 2003; 101(11):4285-9.

7. Gobbi PG, Ferreri AJM, Ponzoni M, Levis A. Hodgkin lymphoma. Crit Rev Oncol Hematol. 2013; 85(2):216-37.

8. DeVitta Jr VT, Costa J. Toward a personalized treatment for Hodgkin's disease. N Engl J Med. 2010; 362(10):942-3.

9. Tedder TF, Streuli M, Schlossman SF, Saito H. Isolation and structure of a cDNA encoding the B1 (CD20) cell-surface antigen of human B lymphocytes. Proc Natl Acad Sci USA. 1988; 85(1):208-12.

10. Einfeld DA, Brown JP, Valentine MA, Clark EA, Ledbetter JA. Molecular cloning of the human $\mathrm{B}$ cell CD20 receptor predicts a hydrophobic protein with multiple transmembrane domains. EMBO J. 1988; 7(3):711-7.

11. Rassidakis GZ, Medeiros J, Viviani S, Bonfante V, Nadali GP, Vassilakopoulos TP, et al. CD20 expression in Hodgkin and Reed-Sternberg cells of classical Hodgkin's disease: associations with presentinf features and clinical outcome. J Clin Oncol. 2002; 20(5):1278-87.

12. Maloney DG. Anti-CD20 antibody therapy for B-cell lymphomas. N Engl J Med. 2012; 366(21):2008-16.

13. Gordon LI, Longnecker R. Off-targeting oft-targeted CD20 in cHL. Blood. 2012; 119(18):4095-6.

14. Oki Y, Younes A. Does rituximab have a place in treating classic Hodgkin lymphoma? Curr Hematol Malig Rep. 2010; 5(3):135-9.

15. Tzankov A, Krugmann J, Fend D, Fischhofer M, Greil R, Dirnhofer S. Prognostic significance of CD20 expression in classical Hodgkin lymphoma. Clin Cancer Res. 2003; 9(4):1381-6.

16. Horvat M, Prevodnik VK, Lavrencak J, Novakovic BJ. Predictive significance of the cut-off value of CD20 expression in patients with B-cell lymphoma. Oncol Rep. 2010; 24(4):1101-7. 